Article

\title{
Research as a Base for Sustainable Development of Universities: Using the Delphi Method to Explore Factors Affecting International Publishing among Vietnamese Academic Staff
}

\author{
Trung Tran ${ }^{1, * \mathbb{C}}$, Thao-Phuong-Thi Trinh ${ }^{2, *}$, Cuong-Minh Le ${ }^{3}$, Linh-Khanh Hoang ${ }^{4,5}$ and \\ Hiep-Hung Pham 6,7 (D) \\ 1 Department of Basic, Vietnam Academy for Ethnic Minorities, Hanoi 100000, Vietnam \\ 2 Department of Mathematics, Thai Nguyen University of Education, Thainguyen 250000, Vietnam \\ 3 Center of Occupational Skills Development, Dong Thap University, Dongthap 870000, Vietnam; \\ lmcuong@dthu.edu.vn \\ 4 Institute of Theoretical and Applied Research, Duy Tan University, Hanoi 100000, Vietnam; \\ hoangkhanhlinh2@duytan.edu.vn \\ 5 Vietnam Journal of Education, Hanoi 100000, Vietnam \\ 6 Center for Research and Practice on Education, Phu Xuan University, Thuathien-Hue 530000, Vietnam; \\ phamhunghiep@pxu.edu.vn \\ 7 Center for Education Research and Development EdLab Aisa, Hanoi 100000, Vietnam \\ * Correspondence: trantrung@hvdt.edu.vn (T.T.); thaottp@tnue.edu.vn (T.-P.-T.T.)
}

Received: 16 March 2020; Accepted: 20 April 2020; Published: 23 April 2020

check for updates

\begin{abstract}
In recent years, the Vietnamese government has put significant effort into the internationalization of research in the higher education system via the use of international publications (i.e., publications indexed by citation databases such as ISI Web of Science and Scopus) in evaluating their academic staff and doctoral students. Academic staff in Vietnam, who traditionally have low numbers of international publications, have thus been pushed to improve their competencies in order to meet the new requirements for research productivity. However, we have little understanding of the factors influencing international publication as perceived by Vietnamese academic staff. This study aims to fill the gap by using the Delphi method. Academic staff with at least one international publication were invited, via purposeful sampling, to participate in a two-round Delphi survey. The survey revealed 14 key factors, which were further classified into three dimensions: "policy-related factors," "capability-related factors," and "networking-related factors". These factors were the key determinants in the success of international publishing, according to the study participants. The findings provide implications for policymakers and university leaders for enhancing the research capacities of Vietnamese universities, forming a basis for the sustainable development of the higher education sector in Vietnam.
\end{abstract}

Keywords: research; international publishing; sustainable development; university; Vietnam; Delphi method

\section{Introduction}

Over the past decade, the Vietnamese government has made efforts to increase the research capacity of Vietnam's higher education system [1-3]. Vietnamese academic staff have been encouraged or, in certain circumstances, required, to submit research to international publications (i.e., publications indexed by citation databases such as ISI Web of Science and Scopus). However, due to a chronic shortage of research competency and skills, along with appropriate supporting policies, many academic staff 
face challenges when trying to publish internationally [4]. Despite growing concern from practitioners in Vietnam about the need to support academic staff to be able to publish internationally, there has been limited research identifying the main factors inhibiting international publishing by Vietnamese academic staff. This study aims to fill the gap in the existing literature. Using the Delphi technique, this study explores the factors influencing the capacity to publish internationally, as perceived by Vietnamese scholars who have experience in this area.

The findings of this study provide several contributions to the field. First, even though the study was designed to use empirical findings from Vietnam, other countries, especially non-English speaking and developing countries, may find it a useful model for comparison and benchmarking. Promoting research through publications in internationally indexed journals cited by ISI Web of Science or Scopus is among the top priorities of many higher education systems across the world, including non-English speaking and developing countries (see $[5,6])$. Research has been identified as an essential function of universities, aside from their traditional teaching functions. Focusing on research will undoubtedly help universities to develop sustainably. Second, policymakers in Vietnam may use the findings of the study as input to their revision of the current macro policy for the academic sector. Third, university leaders can also learn from the results of the study to enable further adjustment regulations at the meso level (i.e., institutional level) for their academic staff.

The paper is structured as follows. In the next section, the prior related literature is reviewed. Specifically, we discuss higher education and research systems in Vietnam; the concept of "international publication" in the context of Vietnam; research performance in Vietnam as seen via international publication databases; and previous studies on factors impacting international publishing by Vietnamese researchers. Subsequently, the Delphi method is described. Next, the findings of the two Delphi rounds are represented. We then discuss the findings and their implications. The final section presents the conclusions and limitations of the study.

\section{Literature}

\subsection{Higher Education and Research Organizations in Vietnam}

Traditionally, Vietnam followed the former Soviet model for higher education and research. Thus, the functions of higher education and research were divided, with universities overseeing higher education and training, while research institutes focused primarily on research. At the present time, this model has been adjusted, and the two functions (i.e., higher education and research) are now assigned to both universities and research institutes. According to Vietnam's Law on Higher Education [7] and Law on Science and Technology [8], universities are institutionalized as both higher education and research organizations, and research institutes have had doctoral education added to their traditional research function. According to the most recent official data, Vietnam had 235 universities in 2017 [9] and 550 research institutes/centers in 2014 [10].

\subsection{The Concept of "International Publication" in the Context of Vietnam}

Akin to the situations observed in other Asian settings such as Korea, China or Taiwan ROC, international publication in the Vietnamese context has two attributes [11]:

First, it is a publication written in English. Despite being a formerly colonized state of France and a member of the former Soviet bloc countries, Vietnam nowadays prefers to use English to French and Russian. English is regarded as the first foreign language $[12,13]$. Within the academic landscape, English has gradually become the lingua franca for Vietnamese scholars [14]. When referring to international publications, Vietnamese scholars often assume that these are manuscripts written in English, even though a certain proportion of Vietnamese scholars are still using other languages such as French, Russian or Chinese as their first foreign language. Our search query on the Scopus database (https://www.scopus.com/home.uri) on April 14, 2020, revealed that of 70,798 publications identified as 
originating in Vietnam, 70,090 were written in English (98.99\%). The corresponding figures for French, Russian and Chinese are $376(0.53 \%), 150(0.21 \%)$ and $90(0.13 \%)$, respectively.

Second, international publication in the Vietnamese context often refers to articles published in internationally indexed databases such as ISI Web of Science and Scopus, the two most prominent indexed databases, which are used by the most reputable university ranking systems, such as Shanghai Jiaotong, THE, and QS. In Vietnam, over the past decade, there has been an increasing trend toward using internationally indexed databases at both the macro (i.e., governmental or ministerial) level and the meso (i.e., institutional) level. Among the government's initiatives, the establishment (in 2003) and official operation (2008) of the National Foundation for Science and Technology Development (NAFOSTED) was the first-ever initiative at the national level aiming to achieve international integration of research in Vietnam [15]. Inspired by the US's National Science Foundation, NAFOSTED used a peer review committee, whose members are elected from the academic community to evaluate and grant funds for research proposals from the academic sector. NAFOSTED requires grantees to have publications published in journals indexed by ISI Web of Science/Scopus databases as prerequisite conditions for project fulfillment. This is what distinguishes NAFOSTED from other research funding mechanisms in Vietnam, which usually only require domestic publications written in Vietnamese.

Another milestone, which highlights the requirement for international publishing in Vietnam's academic sector, was the new regulation on doctoral education issued in 2017 by Vietnam's Ministry of Education and Training (MOET), as Circular 08/2017/TT-BGDĐT [16]. Specifically, the Circular required Vietnamese academic staff to be the first or corresponding author of at least one ISI Web of Science/Scopus publication to be eligible to supervise $\mathrm{PhD}$ candidates. Similarly, a PhD candidate is required to be a co-author of at least one ISI Web of Science/Scopus cited paper in order to graduate. In the following year, new regulations on professorial appointments also used international publication as a prerequisite for the appointment of professors/associate professors [17]. Specifically, a newly appointed professor must have at least five ISI Web of Science/Scopus publications, and an associate professor must have three such publications. In terms of incentives at the institutional level, financial reward for faculty staff who achieve international publication has been the most notable policy applied by Vietnamese universities. As noted by Vuong [15], since 2010, several Vietnamese universities have adopted financial reward policies ranging from USD 650 to USD 10,700 per article published in a journal indexed by the ISI/Scopus databases, depending on the journal's quality.

\subsection{Research Performance of Vietnam as Seen from International Publication Databases}

The research performance of Vietnam, as seen in international publication databases, is modest compared to neighboring countries [18-20], as illustrated in Table 1. Specifically, among the major Southeast Asian countries, in 2018, the research output of Vietnam (6040 in ISI Web of Science; and 8837 in Scimago/Scopus) only outperformed the Philippines (2042-ISI Web of Science; 3775-Scopus) and lagged behind the other four, including Malaysia (15,615-ISI Web of Science; 33,295-Scopus); Indonesia (7474-ISI Web of Science; 32,456-Scopus); Singapore (14,974-ISI Web of Science; 22,495—Scopus); and Thailand (10,867-ISI Web of Science; 17,943—Scopus).

Table 1. Number of publications of six major ASEAN countries as seen. (from ISI Web of Science and Scimago/Scopus).

\begin{tabular}{ccccccc}
\hline & ISI Web of Science & \multicolumn{3}{c}{ Scimago/Scopus } \\
\hline Country & $\begin{array}{c}\text { Number of } \\
\text { Publications in } \\
\mathbf{2 0 1 0}\end{array}$ & $\begin{array}{c}\text { Number of } \\
\text { Publications in } \\
\mathbf{2 0 1 8}\end{array}$ & $\begin{array}{c}\text { Average Growth } \\
\text { Rate 2010-2018 }\end{array}$ & $\begin{array}{c}\text { Number of } \\
\text { Publications in } \\
\mathbf{2 0 1 0}\end{array}$ & $\begin{array}{c}\text { Number of } \\
\text { Publications } \\
\text { in 2018 }\end{array}$ & $\begin{array}{c}\text { Average Growth } \\
\text { Rate 2010-2018 }\end{array}$ \\
\hline Malaysia & $5963(2)$ & $15,615(1)$ & $12.8 \%(3)$ & $15,810(2)$ & $33,295(1)$ & $9.8 \%(4)$ \\
\hline The Philippines & $801(6)$ & $2042(6)$ & $12.4 \%(4)$ & $1355(6)$ & $3775(6)$ & $13.7 \%(3)$ \\
\hline Indonesia & $1039(5)$ & $7474(4)$ & $27.9 \%(1)$ & $2884(4)$ & $32,456(2)$ & $35.3 \%(1)$ \\
\hline
\end{tabular}


Table 1. Cont.

\begin{tabular}{ccccccc}
\hline & \multicolumn{3}{c}{ ISI Web of Science } & \multicolumn{2}{c}{ Scimago/Scopus } \\
\hline Country & $\begin{array}{c}\text { Number of } \\
\text { Publications in } \\
\mathbf{2 0 1 0}\end{array}$ & $\begin{array}{c}\text { Number of } \\
\text { Publications in } \\
\mathbf{2 0 1 8}\end{array}$ & $\begin{array}{c}\text { Average Growth } \\
\text { Rate 2010-2018 }\end{array}$ & $\begin{array}{c}\text { Number of } \\
\text { Publications in } \\
\mathbf{2 0 1 0}\end{array}$ & $\begin{array}{c}\text { Number of } \\
\text { Publications } \\
\text { in 2018 }\end{array}$ & $\begin{array}{c}\text { Average Growth } \\
\text { Rate 2010-2018 }\end{array}$ \\
\hline Singapore & $8920(1)$ & $14,974(2)$ & $6.7 \%(6)$ & $15,767(1)$ & $22,495(3)$ & $4.5 \%(6)$ \\
\hline Thailand & $5257(3)$ & $10,867(3)$ & $9.5 \%(5)$ & $10,192(3)$ & $17,943(4)$ & $7.3 \%(5)$ \\
\hline Vietnam & $1267(4)$ & $6040(5)$ & $21.6 \%(2)$ & $2196(5)$ & $8837(5)$ & $19.0 \%(2)$ \\
\hline
\end{tabular}

* Note: -Rankings of respective countries are noted in parentheses. - ISI Web of Science in this table refers to the SCIE, SSCI, AHCI, ESCI and BKCI sub-databases. Source: authors synthesized from [21,22].

Despite the modest performance in terms of absolute numbers of publications, Vietnam is among the highest performing countries in the region in terms of the growth of international publications over the previous decade (see Table 1). Specifically, between 2010 and 2018, the average growth rate in terms of publications cited in the ISI Web of Science for Vietnamese scholars was 21.6\%; the respective figure in the Scimago/Scopus database was $19.0 \%$. This is in line with the findings of a recent report by Adams, Pendlebury, Rogers, and Szomszor [23], which indicated that the growth rate of publications indexed in SCIE, SSCI, AHCI for Vietnam is the highest among 14 South and Southeast Asian countries during the period 1981-2018.

\subsection{Previous Studies on Factors Impacting International Publishing}

Several previous studies, both in the international and in the Vietnamese context, have examined the factors influencing international publication by academic researchers.

For instance, Chang and Chow [24] conducted a survey with 23 Hong Kongese and Taiwanese scholars with experience publishing in top journals in accounting, and found that "Working on interesting and innovative research topics that contribute to the literature", "Hard work, persistence, motivation and positive attitudes" and "Selecting the right co-authors" were the three most important factors in successful international publishing. Another survey with 14 Chinese authors in management sciences [25] concluded that collaboration, especially with established authors, in conjunction with English academic writing, were key determinants in successful international publishing.

Given the role of English as the lingua franca in the academic sector, publishing in English has become an ongoing issue for scholars worldwide, especially those in non-English speaking countries. This, in turn, has motivated many senior authors to write books to guide junior and/or non-English speaking authors. Some notable texts include those by Corcoran et al., Curry and Lillis, and Wisker [26-28].

In Vietnam, a few studies have aimed to address the factors influencing both international and general publishing (i.e., both domestic and international). Vuong and his associates are among the most active in this field. Using data extracted from the Scopus database in conjunction with data from local sources such as university websites, this research team has produced a series of publications (e.g., see [3,29-33] ) about the research outputs of Vietnamese social scientists and related factors.

Of these publications, Vuong et al. [3] is one of the most notable. The study revealed that collaboration with international colleagues resulted in higher productivity among social scholars in Vietnam. The study also determined that authors affiliated with universities tended to have higher performance than those affiliated with research institutes/centers.

However, these studies all relied on secondary data. Notably, the study by Vuong et al. [3] could not examine the underlying factors perceived by academic staff.

Pham and Hayden [34] overcame Vuong et al.'s [3] limitations by conducting in-depth interviews with 20 Vietnamese researchers. Pham and Hayden's work [34] revealed that English writing competency and funding limitations are among the key factors hindering Vietnamese scholars from publishing internationally. 
However, both Vuong et al.'s studies [3] and the work of Pham and Hayden [34] have a common limitation: they only collected data relating to social researchers and ignored their peers in science and technology. This limitation was addressed by Pho and Tran [4], with the participation of 148 Vietnamese lecturers in their survey. However, their work did not separate the opinions of those who had experience of international publication from those who did not. This could affect the validity of the findings since people who have never published internationally might not have a full understanding of the publication process and its difficulties.

This study aimed to fill the above-identified gaps using the Delphi technique to explore factors impacting international publishing via interviews with 35 scholars in science and technology as well as social sciences, who had experience in publishing at least one ISI Web of Science/Scopus cited paper. The research methods are explained in the next section.

\section{Research Methods}

The Delphi method was used in this study. The method was first developed by RAND Corporation in the 1960s to explore ideas and seek consensus among a panel of experts [35,36]. Nowadays, the method is widely used in a variety of sectors, such as nursing studies [37]; marketing [38]; tourism [39]; urban studies [40]; and education [41]. Given the exploratory nature of this study, using the Delphi method was an appropriate way to address the research goals. According to Keeney, Hasson, and McKenna [37], the Delphi method uses an iterative process to achieve consensus from various experts around a given issue. Since international publication is still a newly emerging and thus, an under-addressed issue in the Vietnamese higher education and research context, consensus among scholars who have experience in international publishing is paramount. The Delphi method usually starts with an interview to explore ideas from experts about the given issue. Based on the results of the interview round (round 1), and in conjunction with literature searching, the researchers then design a questionnaire for the second round. In the second round, experts are asked to complete the questionnaires using a numerical rating scale. They are also asked to provide explanations for their responses and to suggest adjustments to the questionnaires if necessary. Answers and feedback from experts from the first round are used as input for further adjustment of the questionnaire in the next rounds. The iterative process of questionnaire development ends when a predetermined level of agreement among experts is reached [42]. Sometimes, researchers may skip the interview in the first round and the Delphi study then starts with the questionnaires immediately [42].

\section{Participants}

Academic staff who had at least one international publication in ISI Web of Science/Scopus indexed journals were selected to participate in this Delphi study. We invited 51 people who satisfied the above criteria. All these 51 potential participants had personal contacts with the co-authors of this study. According to McKenna [43], since a high response rate in successive rounds in a Delphi survey is important, personal contacts with the study's investigators are decisive factors.

Eventually, 35 individuals agreed to participate in round 1 of the study (a 69\% acceptance rate). Endacott, Clifford, and Tripp [44] recommended that the appropriate number of participants in a study using the Delphi method is between 20 and 50 people. Thus, our Round 1 panel of 35 participants was satisfactory.

\section{Data Collection and Findings}

\subsection{Round 1}

In the first round, we sent an online survey to the 35 participants who agreed to join the Delphi study. Because of its advantage in terms of reducing the time requirements [45], an online survey was selected in this study rather than a traditional pencil-and-paper survey. As all our participants were highly qualified experts, it was assumed that they were familiar with the use of an online survey. 
Because of its simple administration and easy to access, Google Form was selected as the tool for the online survey. Google Form has been used in several recent studies (e.g., see [46]).

There were three main groups of questions in the first round survey. The first part of the survey addressed the personal characteristics of the participants (see Table 2). The second part of the survey included 13 five-point Likert scale items pertaining to 13 factors affecting international publishing (see Table 3). These items were developed based on previous studies relating to our topic, including Pham and Hayden [34]; Chang and Chow [24]; Li [25]; Vuong et al. [3]; Ho et al. [29]; Pho and Tran [4]; Vuong and Tran [32]. The third part of the survey was composed of two open-ended questions. The first asked the respondent whether the terminology in the 13 questions in part 2 needed to be modified or adjusted. The second one asked the respondents to suggest new item(s), other than the initial 13 items, which might affect international publication success, according to their experience. The respondent was also asked to provide his or her explanations for any suggestions, whether these related to adjustments or new items.

Table 2. Personal characteristics of the research participants.

\begin{tabular}{|c|c|c|c|c|}
\hline \multirow{2}{*}{ Characteristics of Participants } & \multicolumn{2}{|c|}{ Round 1} & \multicolumn{2}{|c|}{ Round 2} \\
\hline & Frequency & $\%$ & Frequency & $\%$ \\
\hline \multicolumn{5}{|l|}{ Gender } \\
\hline Male & 23 & $65.7 \%$ & 15 & $75 \%$ \\
\hline Female & 12 & $34.3 \%$ & 5 & $25 \%$ \\
\hline \multicolumn{5}{|l|}{ Age } \\
\hline $26-30$ & 4 & $11.4 \%$ & 3 & $15 \%$ \\
\hline $31-35$ & 11 & $31.4 \%$ & 8 & $40 \%$ \\
\hline $36-40$ & 12 & $34.3 \%$ & 7 & $35 \%$ \\
\hline $41-45$ & 5 & $14.3 \%$ & 1 & $5 \%$ \\
\hline $46-50$ & 3 & $8.6 \%$ & 1 & $5 \%$ \\
\hline \multicolumn{5}{|l|}{ Degree } \\
\hline $\mathrm{PhD}$ & 23 & $65.7 \%$ & 10 & $50 \%$ \\
\hline Masterate & 12 & $34.3 \%$ & 10 & $50 \%$ \\
\hline \multicolumn{5}{|l|}{ International publication record } \\
\hline \multicolumn{5}{|l|}{ Number of ISI Web of Science/Scopus publications as co-author } \\
\hline $1-2$ & 15 & $42.9 \%$ & 6 & $30 \%$ \\
\hline 3 or more & 20 & $57.1 \%$ & 14 & $70 \%$ \\
\hline \multicolumn{5}{|l|}{$\begin{array}{l}\text { Number of ISI Web of Science/Scopus publications as first or } \\
\text { corresponding author }\end{array}$} \\
\hline 0 & 10 & $28.6 \%$ & 5 & $25 \%$ \\
\hline $1-2$ & 14 & $40 \%$ & 8 & $40 \%$ \\
\hline 3 or above 3 & 11 & $31.4 \%$ & 7 & $35 \%$ \\
\hline \multicolumn{5}{|l|}{ Field of research } \\
\hline Science, Technology, Engineering or Mathematics (STEM) & 18 & $51.4 \%$ & 10 & $50 \%$ \\
\hline Social Sciences, Humanities (SSH) or others & 17 & $48.6 \%$ & 10 & $50 \%$ \\
\hline \multicolumn{5}{|l|}{ Experience in the academic sector } \\
\hline Over 15 years & 8 & $22.9 \%$ & 4 & $20 \%$ \\
\hline $10-15$ years & 9 & $25.7 \%$ & 4 & $20 \%$ \\
\hline $5-10$ years & 15 & $42.9 \%$ & 10 & $50 \%$ \\
\hline Under 5 years & 3 & $8.6 \%$ & 2 & $10 \%$ \\
\hline
\end{tabular}


Table 3. Results of the two-round Delphi study.

\begin{tabular}{|c|c|c|c|c|c|c|c|c|}
\hline \multirow[b]{2}{*}{ No } & \multirow[b]{2}{*}{ Item } & \multicolumn{3}{|c|}{ Round $1(n=35)$} & \multirow[b]{2}{*}{ Item } & \multicolumn{3}{|c|}{ Round $2(n=20)$} \\
\hline & & Mean & SD & $\begin{array}{c}\% \text { of } \\
\text { Consensus }\end{array}$ & & Mean & SD & $\begin{array}{c}\% \text { of } \\
\text { Consensus }\end{array}$ \\
\hline 1 & Domestic Scientific documents & 3.429 & 1.092 & $45.7 \%$ & $\begin{array}{l}\text { Accessibility of domestic } \\
\text { scientific documents * }\end{array}$ & 3.85 & 0.813 & $40 \%$ \\
\hline 2 & $\begin{array}{c}\text { International scientific } \\
\text { documents }\end{array}$ & 4.914 & 0.284 & $100 \%$ & $\begin{array}{l}\text { Accessibility of international } \\
\text { scientific documents * }\end{array}$ & 3.9 & 0.852 & $100 \%$ \\
\hline 3 & Research idea/topic & 4.829 & 0.382 & $100 \%$ & Research idea/topic & 4.6 & 0.503 & $100 \%$ \\
\hline 4 & Research data & 4.800 & 0.473 & $97.1 \%$ & Input research data * & 4.5 & 0.688 & $95 \%$ \\
\hline 5 & $\begin{array}{l}\text { Experimental devices or tools, } \\
\text { software for research purposes }\end{array}$ & 4.257 & 0.817 & $82.9 \%$ & $\begin{array}{l}\text { Experimental devices or tools, } \\
\text { software for research } \\
\text { purposes }\end{array}$ & 4.15 & 0.671 & $85 \%$ \\
\hline 6 & $\begin{array}{l}\text { Proficiency in foreign language } \\
\text { reading of scientific documents }\end{array}$ & 4.743 & 0.443 & $100 \%$ & $\begin{array}{c}\text { Proficiency in foreign } \\
\text { language reading of scientific } \\
\text { documents }\end{array}$ & 4.55 & 0.887 & $95 \%$ \\
\hline 7 & $\begin{array}{l}\text { Proficiency in foreign language } \\
\text { writing of scientific documents }\end{array}$ & 4.657 & 0.482 & $100 \%$ & $\begin{array}{c}\text { Proficiency in foreign } \\
\text { language writing of scientific } \\
\text { documents }\end{array}$ & 4.65 & 0.489 & $100 \%$ \\
\hline 8 & $\begin{array}{l}\text { Accessibility of research funding } \\
\text { sources }\end{array}$ & 4.400 & 0.736 & $85.7 \%$ & $\begin{array}{l}\text { Accessibility of research } \\
\text { funding sources }\end{array}$ & 4.5 & 0.761 & $90 \%$ \\
\hline 9 & $\begin{array}{l}\text { Time available for research } \\
\text { purposes }\end{array}$ & 4.457 & 0.611 & $94.3 \%$ & $\begin{array}{l}\text { Time available for research } \\
\text { purposes }\end{array}$ & 4.35 & 0.875 & $95 \%$ \\
\hline 10 & Data analysis capability & 4.343 & 0.591 & $94.3 \%$ & Data analysis capability & 4.4 & 0.598 & $95 \%$ \\
\hline 11 & $\begin{array}{l}\text { Collaboration with domestic } \\
\text { peers }\end{array}$ & 4.114 & 0.718 & $85.7 \%$ & $\begin{array}{l}\text { Collaboration with domestic } \\
\text { peers }\end{array}$ & 3.5 & 1.573 & $80 \%$ \\
\hline 12 & $\begin{array}{l}\text { Collaboration with international } \\
\text { peers }\end{array}$ & 4.286 & 0.667 & $88.6 \%$ & $\begin{array}{l}\text { Collaboration with } \\
\text { international peers }\end{array}$ & 3.75 & 0.851 & $80 \%$ \\
\hline 13 & $\begin{array}{l}\text { Selection of appropriate journal } \\
\text { for submission }\end{array}$ & 4.571 & 0.558 & $97.1 \%$ & $\begin{array}{l}\text { Selection of appropriate } \\
\text { journal for submission }\end{array}$ & 4.15 & 0.587 & $95 \%$ \\
\hline 14 & l & 1 & l & 1 & Research framework ** & 4.4 & 0.681 & $80 \%$ \\
\hline 15 & l & l & l & l & $\begin{array}{l}\text { Having a research assistant } \\
\text { (e.g., masters'/PhD student) }{ }^{* *}\end{array}$ & 4.3 & 0.571 & $60 \%$ \\
\hline 16 & l & l & l & l & $\begin{array}{l}\text { Experience and knowledge in } \\
\text { responding to reviewers ** }\end{array}$ & 4.3 & 0.657 & $80 \%$ \\
\hline
\end{tabular}

Table 2 presents the personal characteristics of the 35 survey participants. Specifically, among these 35 participants, 23 (or 65.7\%) were male; and 12 (34.3\%) were female. Most of our participants were $31-35$ years of age (11 people, $31.4 \%$ ) or $36-40$ years of age $(12,34.3 \%)$. The rest were in the age groups $26-30(4,11.4 \%) ; 41-45(14.3 \%)$; and $46-50$ (3, 8.6\%). None of the participants was aged under 26 or over 50. In terms of qualifications, 23 people (or 65.7\%) held PhD degrees whereas 12 people (or $34.2 \%$ ) held master's degrees. All our participants had experience with international publishing. This was particularly important since according to the Delphi method's requirements, participants are required to be experts or experienced people within the topic of the research. However, there was a limitation in that not all participants had published internationally as first or corresponding author (10 people or $28.6 \%$ ). This limitation will be explained at the end of this paper. Regarding participants' field of research, of the 35, 18 were STEM experts $(51.4 \%)$ and 17 were SSH or other experts $(48.6 \%)$. In terms of experience in the academic sector, those with 5-10 years' experience were the largest proportion (15 people, $42.9 \%)$, followed by $10-15$ years $(9,25.7 \%)$, over 15 years $(8,22.9 \%)$, and under 5 years $(3,8.6 \%)$.

The main results of Round 1 are presented in Table 3. Along with the mean and standard deviation pertaining to each item, Table 3 also represents the proportion of consensus, which is an indispensable part of the use of the Delphi technique. According to Keeney, Hasson, and McKenna [47], an item is defined as reaching consensus among participants in a Delphi study when at least $75 \%$ of respondents score strongly agree (i.e., 5 on a 5-point Likert scale) or agree (i.e., 4 on a 5-point Likert scale). As shown in Table 3, of the 13 items, 12 reached the predetermined consensus level of $75 \%$. The only one that did not reach consensus was "Domestic scientific documents" (item 1). Three items (1,2 and 4) received 
suggestions for adjustment in terms of terminology, and an extra three (items 14-16) were suggested for inclusion in the next round of the study (see Table 3).

\subsection{Round 2}

In Round 2, the questionnaires included 16 items in which 13 items were based on Round 1 and three others ("Research framework," "Having research assistant (e.g., masters/PhD student)" and "Experience and knowledge in review answering" (items 14-16)) were added according to suggestions from the participants in Round 1. Personal emails were sent to all 35 participants who had participated in Round 1 to invite them to continue in Round 2. Since all the respondents were active researchers, it was possible they could be too busy to attend to the Round 2 invitation emails. Therefore, reminder emails were delivered to those who did not answer the Round 2 email survey invitation within two weeks. In total, we only obtained 20 acceptances for participation in Round 2, meaning that 15/35 (or $42.8 \%$ ) respondents dropped out of our study after round 1. Drop out between rounds in studies using the Delphi method a natural phenomenon due to time constraints or lack interest on behalf of participants [48]. For instance, Clark [49] reported that in his Delphi study, 4/16 respondents dropped out between Round 1 and Round 3, which implied a dropout rate of $25 \%$.

Table 2 lists the personal characteristics of the 20 experts who agreed to continue in Round 2. In Round 2, fifteen were male (75\%) while the rest were female $(5,25 \%)$. The majority, as in Round 1 , were still in the age categories of $31-35$ years $(8,40 \%)$ and $36-40$ years $(7,35 \%)$. The remaining age categories were $26-30(3,15 \%) ; 41-45(1,5 \%)$; and $46-50(1,5 \%)$. Half of the participants (10 people) in Round 2 held a PhD degree and the other half held a Masters' degree. With regard to international publishing, 6 participants (30\%) had published 1-2 papers, while 14 others $(70 \%)$ had published 3 or more papers. However, 5 participants $(25 \%)$ had never published a paper as first or corresponding author; the respective figures for 1-2 papers and 3 papers or above are $8(40 \%)$ and $7(35 \%))$. In terms of field of research, our 20 participants in Round 2 were divided into two equal groups of 10 each: STEM and SSH or others. In terms of experience in the academic sector, the group with 5-10 years' experience still dominated, with 10 participants (50\%). This was followed by the group with 10-15 years' experience $(4,20 \%)$; over 15 years' experience $(4,20 \%)$; and under 5 years' experience $(2,10 \%)$.

The results of Round 2 are presented in Table 3. The results of Round 1 were all confirmed: 12 items (from 2 to 13) reached consensus, while one item (item 1) did not. For the three newly added items in round 2 (items 14-16), two items (item 14 and 16) reached consensus, with $80 \%$ of respondents answering "agree" or "strongly agree," and one item (item 15) did not, with only $60 \%$ of respondents answering "agree" or "strongly agree."

Thus, after two rounds of the Delphi survey, we explored 14 factors, corresponding to the 14 items that reached consensus in the questionnaires, which affect international publishing, according to our surveyed experts. These were: "Accessibility of international scientific documents"; "Research idea/topic"; "Input research data"; "Experimental devices or tools, software used for research purposes"; "Proficiency in foreign language reading of scientific documents"; "Proficiency in foreign language writing of scientific documents"; "Accessibility of research funding"; "Time available for research purposes"; "Data analysis capability"; "Collaboration with domestic peers"; "Collaboration with international peers"; "Selection of an appropriate journal for submission"; "Research framework"; and "Experience and knowledge in responding to reviewers".

\section{Discussion and Implications}

International publishing has gained increasing attention in the Vietnamese academic community in recent years $[1,15,20]$. This is a result of the on-going higher education internationalization implemented by the Vietnamese government and universities [1,3]. Traditionally, universities in Vietnam mostly focused on teaching. Nowadays, they are highly aware of the importance of research, especially research of an international standard (i.e., in internationally indexed publications) as the foundation for their sustainable development. However, there is little understanding of the factors 
influencing international publishing by academic staff in Vietnam. To address this issue, this study used the Delphi method to reach agreement among a panel of academic staff from different fields in Vietnam, who had experience in international publication. Thus, after two rounds of the survey, we found 14 factors that might lead to success in international publishing, according to the sampled respondents. These 14 factors were further regrouped into three clusters influencing international publishing by academic staff in Vietnam: "policy-related factors," "capability-related factors", and "networking-related factors" (Figure 1). The name of each dimension reflects the attribute of their respective factors. For instance, the dimension of "capacity-related" refers to the factors pertaining to knowledge, skills and experiences of researchers in international publishing. Similar principles are also applied for naming of "policy-related" and "networking-related" dimensions. These three dimensions interact together to influence the success of international publishing.
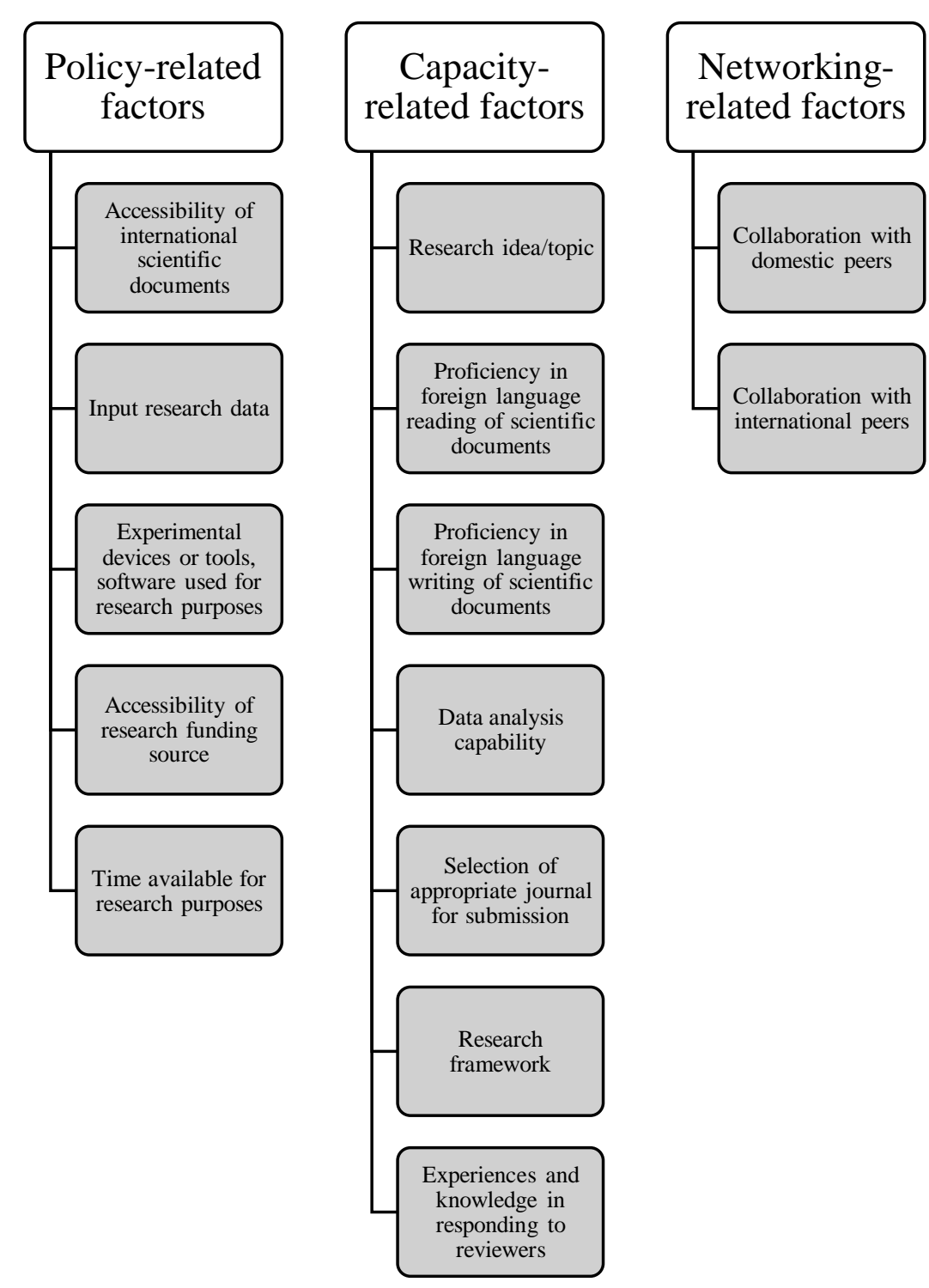

Figure 1. Factors impacting on international publishing of academic staff in Vietnam.

\subsection{Policy-Related Factors}

Prior literature has shown the importance of governmental as well as institutional policies in the research outcomes of faculty members [1,32]. Therefore, it is not surprising that our sampled panelists emphasized the role of "policy-related factors" in their success in international publishing, 
including: "Accessibility of international scientific documents" (item 2); "Input research data" (item 4); "Experimental devices or tools, software used for research purposes" (item 5); "Accessibility of research funding" (item 8); "Time available for research purposes" (item 9).

"Accessibility of international scientific documents" gained the highest level of agreement among respondents, with scores of $100 \%$ in both rounds. Highlighting the importance of "accessibility in international scientific documents," reflects a chronic shortage of referencing resources, which is common in developing countries [50]. Such a shortage also applies in Vietnam's context: recent unofficial evidence indicates that only $10 \%$ of Vietnamese universities have digital libraries connecting to international academic databases such as ScienceDirect or Elsevier, confirming the issue mentioned above [51].

Nowadays, many scholars use secondary data for their research analysis (e.g., see [32]). Therefore, accessing research data is paramount [52,53]. Academic database providers often sell subscriptions to access secondary data resources, along with publication resources. Given this, the importance of "input research data" as perceived by our sample is obviously associated with the factor of "Accessibility of international scientific documents."

"Experimental devices or tools, software for research purposes" is a crucial driver of international publishing, according to our findings. This is in line with several previous studies. For instance, Olmsted et al. [54] observed in the public health sector that "access to reliable laboratory testing remains limited in many resource-limited countries" (p. 374). Similarly, unauthorized use of academic software was identified as one of the most common forms of software piracy in developing countries, according to Zoheir and Mohammed [55].

Along with the shortage of "Experimental devices or tools, software for research purposes," shortage of research funding ("Accessibility of research funding") is another significant difficulty for Vietnamese researchers, as found in our survey. Available data shows that investment in R\&D in Vietnam is relatively lower than in other countries in the region [19]. However, the absolute value of research funding is only part of the problem; the other part pertains to issues of transparency and fairness [56]. According to Vuong [15] and Tran et al. [57], NAFOSTED is an exceptional governmental funding source that is appreciated by the academic community in Vietnam thanks to its international standards in terms of operation. The others are often seen as highly bureaucratic, non-transparent, and even corrupt [58].

"Time available for research purposes" is the last factor under the dimension of "policy-related" [4]. In Vietnam, since most universities are teaching institutions, staff are often overwhelmed with teaching workloads and do not have enough time for research activities [56]. It is also worth noting that sabbatical leave, which is often used by faculty staff in developed countries as a time to focus on research, is uncommon in actual practice in the academic sector in Vietnam at present [59].

\subsection{Capability-Related Factors}

The "capability-related" dimension refers to the knowledge, skills and experience of scholars during different phases of research such as: identifying research ideas/topics and frameworks; literature reviewing, data analysis, manuscript writing, manuscript submission and responding to reviewers' comments. These phases are consistent with the seven factors shown in Figure 1. "Research idea/topic," "research framework," and " data analysis capability" are the three essential drivers of quality research, according to previous studies [4].

Having an awareness of the importance of these above factors, curriculum designers in universities worldwide have placed research methods courses at the center of their Masterate and $\mathrm{PhD}$ programs with the aim of giving their early career researchers the necessary research knowledge and skills for a future academic career (see [60,61]). Since all our participants had experience publishing internationally, and many of them had graduated overseas, it is understandable that they all acknowledged the need for research knowledge and skills. 
"Proficiency in foreign language reading of scientific documents" and "Proficiency in foreign language writing of scientific documents" are the two other factors that can be obstacles for Vietnamese scholars wanting to publish in international journals. These findings are in line with previous studies conducted in the Vietnamese context (e.g., [4,32,56]) and in other non-native English-speaking countries (e.g., [62]).

The two last factors in the "capability-related" dimension are "Selection of appropriate journal for submission" and "Experience and knowledge in responding to reviewers." While the former is consistent with Pho and Tran's finding [4], which also selected Vietnamese scholars as respondents, the latter is not. It might be because our respondents were at the 'expert' level as required by the Delphi method; thus, they had more experience in research publishing and were more aware of the obstacles during the reviewing process.

\subsection{Networking-Related Factors}

"Networking-related" is the last dimension relating to success in international publication of research. The dimension is composed of two factors: "Collaboration with domestic peers" and "Collaboration with international peers." Previous studies also assessed the impacts of these two factors on scholars' publication outcomes. For instance, Vuong et al. [63], using data from Scopus between 2008 and 2017, found that $90 \%$ of Vietnamese social scientists collaborated with colleagues to publish. Vuong and his colleagues also found that collaboration with domestic and international colleagues enhanced researchers" productivity [3]. A later study also conducted by Vuong and his research team (see [64]) further strengthened and expanded the above finding. Specifically, these authors asserted that in order to "reach and maintain high productivity levels", a research community must satisfy four criteria:" (i) a stable co-authorship network, (ii) support from foreign colleagues in the field, (iii) outstanding research leaders, and (iv) a sustainable inflow of new researchers" (p.77). All of these four criteria are relevant to the "networking-related factors" in our study.

\subsection{Factors That Did Not Reach Consensus}

There were two factors that did not reach consensus among our panelists. These were: "Accessibility of domestic scientific documents" and "Having a research assistant (e.g., masters'/PhD student)." Since the purpose here is to publish internationally, the rejection of the former factor ("Accessibility of domestic scientific documents") is understandable. However, the rejection of the latter factor is somewhat surprising, and it is not consistent with previous studies. For instance, Larivière [65] noted that PhD students in Canada are part of their supervisors' research groups (along with other members such as post-doc fellows or technical officers), contributing to the overall performance of the group. Specifically, Larivière's findings [65] indicated that between 2000-2007, PhD students co-authored 33\% of the total publications in Quebec province, Canada. Our contradictory finding can be explained by consideration of the particular context of the Vietnamese research landscape. We propose some plausible explanations, as follows. First, Vietnamese scholars have experienced having poorly qualified graduate students. As one of the most significant sources of international students in Asia, many young Vietnamese go abroad every year to undertake degree studies [66]. Many of these are talented and have scholarships to study in developed countries. Consequently, those who stay home to pursue graduate education are under-qualified compared to the expectations of our scholar panelists. Thus, professors and senior lecturers in Vietnam tend not to regard $\mathrm{PhD}$ and Masterate students as essential factors in their research teams. Second, another possible interpretation is because Vietnam lacks appropriate policies to support PhD students: the majority of PhD students in Vietnam are self-funded and studying part-time while also working to support themselves, meaning that they may not be able to concentrate fully on their research. Given these circumstances, it is understandable that senior scholars in Vietnam are not willing to collaborate with their PhD students in international publishing. 


\section{Conclusions, Implications, and Limitations}

International publishing is playing an increasing role in the internationalization of higher education and research systems in Vietnam. At present, the "absolute" performance in terms of international publishing by Vietnamese researchers is still modest. However, when examining the growth trend, Vietnam performs better than many other countries in the region [23]. Given this circumstance, the aim of this study was to explore the key factors that create success for Vietnamese scholars in international publishing (i.e., articles published in journals/books indexed by ISI Web of Science/Scopus databases). Using a Delphi approach to collect opinions from a panel of scholars, this study found 14 factors that affect international publishing by Vietnamese academics. These 14 factors are further classified into three dimensions: "policy-related factors," "capability-related factors," and "networking-related factors."

The findings of this study provide implications for a range of stakeholders. Specifically, they may act as inputs for further adjustment in terms of policy, incentives, and regulations at both national and institutional levels.

First, the Vietnamese government and universities should invest more profoundly in e-resources, to enable their academic staff to access international scientific documents, data, and software for research purposes. To do this, some "best practices" learned from the US's information and library services consortiums should be taken into consideration. For instance, the South Carolina Information and Library Services Consortium, shared among 11 public two-year Colleges in South Carolina, which was initiated in 1995, has shown multiple benefits for users, such as a union online catalog, sharing of financial resources, expertise, and learning opportunities [67].

Second, apart from e-resources, the current management of tangible resources, such as experimental devices and tools or laboratory facilities, needs to be overhauled. Currently, at the national level, tangible resources for research are under the auspices of the Ministry of Planning and Investment, which is separated from research grants, which are overseen by the Ministry of Science and Technology. A further adjustment that unifies the national management of tangible research resources and research grants into a single governing body would enhance the effectiveness and efficiency of research funding in Vietnam.

Third, apart from the unification mentioned above, further policies relating to research grants in Vietnam should emphasize international publication as a mandatory output of nationally funded research projects. At present, NAFOSTED is the only research funder in Vietnam that has such a requirement.

Fourth, further policies at both national and institutional levels need to be adjusted in order to create favorable conditions and enhance researchers" capability. For example, sabbatical leave should be adopted in order to enhance "time for research" for Vietnamese scholars.

In addition, short-term fellowship programs, which encourage faculty mobility both domestically and internationally, would be a measure to simultaneously address the multiple factors included in the "capacity-related" and "networking-related" dimensions, as shown in Figure 1. To date, the Vietnamese government seems to have over-emphasized scholarship programs to send young faculty to study for PhDs abroad, but neglected post-doc fellowship programs to nurture scholars at that level.

Furthermore, the current curricula of masters and doctoral programs in Vietnam should be reformed with more credits assigned to research method courses. This would be an appropriate measure that would result in capability building for the next generation of scientists in Vietnam.

Fifth, further policies should be adjusted in order to promote closer co-operation between senior scholars and their Masterate and PhD students. This is particularly crucial for the sustainable development of the academic sector, as indicated in several previous studies $[65,68]$. For example, universities and research institutions in Vietnam might include the number of co-publications (between professors/senior lecturers) as criteria for periodic evaluation and promotion of their senior scholars. Another intervention could be a requirement that research funding agencies demand that their grantees involve Masterate and PhD students as official members of the research project. 
All studies have their own limitations, and this is no exception. First, prior studies in related areas in Vietnam have revealed that there may be several differences in terms of research outputs/behaviors stemming from different groups of authors. For instance, Doan et al. [69] found that male social scientists in Vietnam tend to have higher productivity than their female peers. Due to the small data sample, our study could not reconfirm this finding. Future researchers may be able to investigate to what extent productivity differs in other groups of participants, according to their gender, or other attributes such as fields of research (e.g., Science, Technology, Engineering and Mathematics (STEM) vs. non-STEM), age, or type of institutions.

A second limitation lies in our participant sample. Specifically, as shown in Table 2, 10/35 respondents in Round 1 and 5/20 respondents in Round 2 had never had an international publication as first or corresponding author. To that extent, they were not really "experts" as required by the Delphi Method and as benchmarked with standards from developed academic systems. This was due to the difficulties we experienced in approaching high-performing experts, who were prepared to commit to spending the necessary time to complete both Rounds of our study. Further study, also using the Delphi method, is recommended to take this issue into consideration.

A third limitation of this study pertains to the nature of the Delphi method. While the Delphi method helped to explore the factors impacting international publishing, it could not estimate the relative importance of these factors. For example, the work of Vuong et al. [3] revealed that in Vietnam, social scholars affiliated with universities outperform their peers affiliated with research institutes/centers. In this study, due to the nature of the Delphi method, we could not find empirical evidence to verify this finding. In the light of this, further studies might adopt other approaches such as an Analytical Hierarchy Process (AHP) (see [70]) or a Structural Equation Model (SEM) (see [71]) in order to quantify the relative weights of different factors as predictors of international publishing as perceived by Vietnamese scholars. Practical implications drawn from the quantitative findings of a study using AHP or SEM would possibly be more insightful than those using non-parametric approaches, as used in this study.

Author Contributions: Conceptualization, T.T.; methodology, H.-H.P.; writing-original draft preparation, T.-P.-T.T.; writing-review and editing, T.-P.-T.T. and L.-K.H.; supervision, T.T. and C.-M.L. All authors have read and agreed to the published version of the manuscript.

Funding: This research was funded by the Vietnam National Foundation for Science and Technology Development (NAFOSTED) under grant number 503.01-2019.306.

Acknowledgments: We sincerely thank the reviewers for their valuable comments, which helped us improve the quality of the paper.

Conflicts of Interest: The authors declare no conflicts of interest.

\section{References}

1. Nguyen, T.-L.-H.; van Gramberg, B. University strategic research planning: A key to reforming university research in Vietnam? Stud. High. Educ. 2018, 43, 2130-2147. [CrossRef]

2. Vuong, Q.-H. Breaking barriers in publishing demands a proactive attitude. Nat. Hum. Behav. $2019,3$. [CrossRef] [PubMed]

3. Vuong, Q.H.; Napier, N.K.; Ho, T.M.; Nguyen, V.H.; Vuong, T.T.; Pham, H.H.; Nguyen, H.K.T. Effects of work environment and collaboration on research productivity in Vietnamese social sciences: Evidence from 2008 to 2017 scopus data. Stud. High. Educ. 2019, 44, 2132-2147. [CrossRef]

4. Pho, P.-D.; Tran, T.-M.-P. Obstacles to Scholarly Publishing in the Social Sciences and Humanities: A Case Study of Vietnamese Scholars. Publications 2016, 4, 19. [CrossRef]

5. Altbach, P.G. Peripheries and centers: research universities in developing countries. Asia Pac. Educ. Rev. 2009, 10, 15-27. [CrossRef]

6. Salager-Meyer, F. Scientific publishing in developing countries: Challenges for the future. J. Engl. Acad. Purp. 2008, 7, 121-132. [CrossRef] 
7. Vietnam National Assembly. Law No. 08/2012/QH13: Higher Education Law. 2012. Available online: https:/thuvienphapluat.vn/van-ban/giao-duc/Luat-Giao-duc-dai-hoc-2012-142762.aspx (accessed on 8 March 2020).

8. Vietnam National Assembly. Law No. 29/2013/QH13: Science and Technology Law. 2013. Available online: https://thuvienphapluat.vn/van-ban/Cong-nghe-thong-tin/Luat-khoa-hoc-va-cong-nghe-nam-2013197387.aspx (accessed on 8 March 2020).

9. Vietnam Ministry of Education and Training. Higher Education Statistics 2017-2018. 2019. Available online: https://moet.gov.vn/thong-ke/Pages/thong-ko-giao-duc-dai-hoc.aspx?ItemID=5877 (accessed on 8 March 2020).

10. Vietnam Ministry of Education and Training. Science and Technology Potential in 2014. 2017. Available online: https://www.most.gov.vn/vn/tin-tuc/11501/so-lieu-thong-ke.aspx (accessed on 8 March 2020).

11. Flowerdew, J.; Li, Y. English or Chinese? The trade-off between local and international publication among Chinese academics in the humanities and social sciences. J. Second Lang. Writ. 2009, 18, 1-16. [CrossRef]

12. Nguyen, N. How English has displaced Russian and other foreign languages in Vietnam since 'Doi Moi.'. Int. J. Hum. Soc. Sci. 2012, 2, 259-266.

13. Wright, S. Language education and foreign relations in Vietnam. In Language Policies in Education: Critical Issues; Psychology Press: London, UK, 2002; pp. 225-244.

14. Vu, N.; Burns, A. English as a medium of instruction: Challenges for Vietnamese tertiary lecturers. J. Asia TEFL 2014, 11, 1-33.

15. Vuong, Q.-H. The harsh world of publishing in emerging regions and implications for editors and publishers: The case of Vietnam. Learned Publ. 2019, 32, 314-324. [CrossRef]

16. Vietnam Ministry of Education and Training. Circular No. 08/2017/TT-BGDDT: Introducing Regulations on Doctoral Enrolment and Training. 2017. Available online: https://huvienphapluat.vn/van-ban/Giaoduc/Thong-tu-08-2017-TT-BGDDT-Quy-che-tuyen-sinh-dao-tao-trinh-do-tien-si-338487.asp (accessed on 8 March 2020).

17. Prime Minister of Vietnam. Decision No. 37/2018/QD-TTg: Standards and Procedures for Consideration of Recognition of Accreditation and Appointment to Professor or Associate Professor Title; Procedures for Cancellation of Recognition and Removal of Professor or Associate Professor Ti. 2018. Available online: https://thuvienphapluat.vn/van-ban/Giao-duc/Quyet-dinh-37-2018-QD-TTg-thu-tuc-xet-cong-nhandat-tieu-chuan-va-bo-nhiem-giao-su-pho-giao-su-394211.aspx (accessed on 8 March 2020).

18. Manh, H.D. Scientific publications in Vietnam as seen from Scopus during 1996-2013. Scientometrics 2015, 105, 83-95. [CrossRef]

19. Nguyen, V.-T.; Pham, T.-L. Scientific output and its relationship to knowledge economy: An analysis of ASEAN countries. Scientometrics 2011, 89, 107-117. [CrossRef]

20. Pham, D.-H. A comparative study of research capabilities of East Asian countries and implications for Vietnam. High. Educ. 2010, 60, 615-625. [CrossRef]

21. ISI Web of Science. Available online: https://mjl.clarivate.com/home (accessed on 8 March 2020).

22. Scopus. Scimagojr. Available online: https://www.scimagojr.com/ (accessed on 8 March 2020).

23. Adams, J.; Pendlebury, D.; Rogers, G.; Szomszor, M. Global Research Report on South and Southeast Asia; Clarivate Analytics: Philadelphia, PA, USA, 2019.

24. Chang, O.H.; Chow, C.W. Publishing in Internationally Respected Accounting Journals: Insights and Suggestions of Successful Chinese Authors. Asia-Pac. J. Acc. 1998, 5, 150-165. [CrossRef]

25. Li, Y. Seeking entry to the North American market: Chinese management academics publishing internationally. J. Engl. Acad. Purp. 2014, 13, 41-52. [CrossRef]

26. Corcoran, J.N.; Englander, K.; Muresan, L.-M. (Eds.) Pedagogies and Policies for Publishing Research in English-Local Initiatives Supporting International Scholars; Routledge: London, UK, 2019.

27. Curry, M.J.; Lillis, T. A Scholar's Guide to Getting Published in English; Multilingual Matters: Bristol, UK, 2013.

28. Wisker, G. Getting Published: Academic Publishing Success (Palgrave Research Skills), 2015 ed.; Palgrave Macmillan: London, UK, 2015.

29. Ho, M.T.; Nguyen, T.H.K.; Vuong, T.T.; Vuong, Q.H. On the Sustainability of Co-Authoring Behaviors in Vietnamese Social Sciences: A Preliminary Analysis of Network Data. Sustainability 2017, 11, 2142. [CrossRef]

30. Vuong, Q.H.; La, V.P.; Vuong, T.T.; Ho, M.T.; Nguyen HK, T.; Nguyen, V.H.; Ho, M.T. An open database of productivity in Vietnam's social sciences and humanities for public use. Sci. Data 2018, 5, 180188. [CrossRef] 
31. Vuong, Q.H.; Le, A.V.; La, V.P.; Hoang, P.H.; Ho, M.T. Making social sciences more scientific: Literature review by structured data. MethodsX 2020, 7, 100818. [CrossRef]

32. Vuong, Q.H.; Tran, T. The Vietnamese Social Sciences at a Fork in the Road; Sciendo: Warsaw, Poland, 2019.

33. Vuong, T.T.; Nguyen, T.H.K.; Ho, M.T.; Ho, M.T.; Vuong, Q.H. The (In) Significance of Socio-Demographic Factors as Possible Determinants of Vietnamese Social Scientists' Contribution-Adjusted Productivity: Preliminary Results from 2008-2017 Scopus Data. Societies 2017, 8, 3. [CrossRef]

34. Pham, T.-L.; Hayden, M. Research in Vietnam: The Experience of The Humanities and Social Sciences. J. Int. Comp. Educ. 2019, 8, 27-40. [CrossRef]

35. Gordon, T.J. The Delphi Method. In Futures Research Methodology V2.0; Glenn, J.C., Gordon, T.J., Eds.; American Council for the UNU, 2003.

36. Linstone, H.A.; Turoff, M. (Eds.) The Delphi Method: Techniques and Applications, 1st ed.; Addison-Wesley Educational Publishers Inc: Boston, MA, USA, 1975.

37. Keeney, S.; Hasson, F.; McKenna, H.P. A critical review of the Delphi technique as a research methodology for nursing. Int. J. Nurs. Stud. 2001, 38, 195-200. [CrossRef]

38. Bonnemaizon, A.; Cova, B.; Louyot, M.-C. Relationship Marketing in 2015. Eur. Manag. J. 2007, 25, 50-59. [CrossRef]

39. Chen, L.; Ng, E.; Huang, S.-C.; Fang, W.-T. A Self-Evaluation System of Quality Planning for Tourist Attractions in Taiwan: An Integrated AHP-Delphi Approach from Career Professionals. Sustainability 2017, 9, 1751. [CrossRef]

40. Perveen, S.; Kamruzzaman, M.; Yigitcanlar, T. Developing Policy Scenarios for Sustainable Urban Growth Management: A Delphi Approach. Sustainability 2017, 9, 1787. [CrossRef]

41. Popov, V.; Jiang, Y.; So, H.-J. Shared lessons in mobile learning among K-12 education, higher education and industry: An international Delphi study. Educ. Technol. Res. Dev. 2019. [CrossRef]

42. Irvine, F. Exploring district nursing competencies in health promotion: The use of the Delphi technique. J. Clin. Nurs. 2005, 14, 965-975. [CrossRef]

43. McKenna, H.P. The Delphi technique: A worthwhile research approach for nursing? J. Adv. Nurs. 1994, 19, 1221-1225. [CrossRef]

44. Endacott, R.; Clifford, C.M.; Tripp, J.H. Can the needs of the critically ill child be identified using scenarios? Experiences of a modified Delphi study. J. Adv. Nurs. 1999, 30, 665-676. [CrossRef]

45. Wong, C. How Will the e-Explosion Affect How We Do Research? Phase 1: The E-DEL+ I Proof-of-Concept Exercise; Rand Publishing: Santa Monica, CA, USA, 2003.

46. Nguyen, M.H.; Serik, M.; Vuong, T.T.; Ho, M.-T. Internationalization and Its Discontents: Help-Seeking Behaviors of Students in a Multicultural Environment Regarding Acculturative Stress and Depression. Sustainability 2019, 11, 1865. [CrossRef]

47. Keeney, S.; Hasson, F.; McKenna, H. Consulting the oracle: Ten lessons from using the Delphi technique in nursing research. J. Adv. Nurs. 2006, 53, 205-212. [CrossRef]

48. Franklin, K.K.; Hart, J.K. Idea Generation and Exploration: Benefits and Limitations of the Policy Delphi Research Method. Innov. High. Educ. 2006, 31, 237-246. [CrossRef]

49. Clark, T.G. Defining a Competency Framework to Shape the Professional Education of National Security Master Strategists: A Web-Based Delphi Study; Texas A \& M University: College Station, TX, USA, 2006.

50. Abu-Zidan, F.M.; Rizk, D.E.E. Research in developing countries: Problems and solutions. Int. Urogynecol. J. 2005, 16, 174-175. [CrossRef] [PubMed]

51. Pham, H.-H. University 4.0. 2018. Available online: http://antgct.cand.com.vn/Nguoi-trong-cuoc/Dai-hocbon-cham-khong-517499/ (accessed on 8 March 2020).

52. Cowton, C.J. The Use of Secondary Data in Business Ethics Research. J. Bus. Ethics 1998, 17, $423-434$. [CrossRef]

53. Johnston, M.P. Secondary Data Analysis: A Method of which the Time Has Come. Qual. Quant. Methods Libra. 2014, 3, 619-626.

54. Olmsted, S.S.; Moore, M.; Meili, R.C.; Duber, H.C.; Wasserman, J.; Sama, P.; Hilborne, L.H. Strengthening Laboratory Systems in Resource-Limited Settings. Am. J. Clin. Pathol. 2010, 134, 374-380. [CrossRef]

55. Zoheir, T.; Mohammed, A. Software Piracy in Developing Countries: Prevalence, Causes and Some Propositions. Glob. J. Econ. Bus. 2017, 3, 191-216. [CrossRef] 
56. Nguyen, H.-Q. The influences of research environment within a university on research productivity of academic staff-a case study in a research-oriented university in Vietnam. Int. J. Arts Sci. 2014, 7, 189.

57. Tran, T.; Trinh, T.P.T.; Vuong, T.T.; Pham, H.H. The Debates and the Long-Awaited Reform. In The Vietnamese Social Sciences at a Fork in the Road; Vuong, Q., Tran, T., Eds.; Walter de Gruyter: Berlin, Germany, 2019; pp. 17-32.

58. Tuy, H. Có nên đấu thầu đề tài nghiên cứu khoa học? (Bidding for scientific research, should or shouldn't?) Tia Sang. 2006. Available online: http://tiasang.com.vn/-dien-dan/co-nen-dau-thau-de-tai-nghien-cuu-khoahoc-265 (accessed on 8 March 2020).

59. Sima, C.M. The Role and Benefits of the Sabbatical Leave in Faculty Development and Satisfaction. New Directions Inst. Res. 2020, 2000, 67-75. [CrossRef]

60. Ferguson, S.L.; Hovey, K.A.; Henson, R.K. Quantitative Preparation in Doctoral Education Programs: A Mixed-Methods Study of Doctoral Student Perspectives on their Quantitative Training. Int. J. Dr. Stud. 2017, 12, 137-156. [CrossRef]

61. Leech, N.; Haug, C.A. Investigating Graduate Level Research and Statistics Courses in Schools of Education. Int. J. Dr. Stud. 2015, 10, 093-110. [CrossRef]

62. Huang, J.C. Publishing and learning writing for publication in English: Perspectives of NNES PhD students in science. J. Engl. Acad. Purp. 2010, 9, 33-44. [CrossRef]

63. Vuong, Q.-H.; Ho, M.-T.; Vuong, T.-T.; Nguyen, V.-H.; Napier, N.; Pham, H.-H. Nemo Solus Satis Sapit: Trends of Research Collaborations in the Vietnamese Social Sciences, Observing 2008-2017 Scopus Data. Publications 2017, 5, 24. [CrossRef]

64. Le, T.T.H.; Pham, H.H.; La, V.P.; Vuong, Q.H. The faster-growing fields. In The Vietnamese Social Sciences at a Fork in the Road; Vuong, Q.H., Tran, T., Eds.; Sciendo: Warsaw, Poland, 2019; pp. 52-79.

65. Larivière, V. On the shoulders of students? The contribution of PhD students to the advancement of knowledge. Scientometrics 2012, 90, 463-481. [CrossRef]

66. Lai, S.; Pham, H.-H.; Nguyen, H.-K.; Nguyen, T.-C.; Le, A.-V. Toward Sustainable Overseas Mobility of Vietnamese Students: Understanding Determinants of Attitudinal and Behavioral Loyalty in Students of Higher Education. Sustainability 2019, 11, 383. [CrossRef]

67. Erb, R.A. The Evolution of a Technical College Regional Library Network. Community Jr. College Libr. 2008, 14, 299-312. [CrossRef]

68. van Rensburg, G.H.; Mayers, P.; Roets, L. Supervision of post-graduate students in higher education. Trends Nurs. 2016, 3, 163-179. [CrossRef]

69. Doan, X.H.; Nguyen, T.P.T.; La, V.P.; Nguyen, T.H.K. Researchers who lead the trends. In The Vietnamese Social Sciences at a Fork in the Road; Vuong, Q.H., Tran, T., Eds.; Sciendo: Warsaw, Poland, 2019; pp. 98-120.

70. Zhao, S.L.; Song, W.; Zhu, D.Y.; Peng, X.B.; Cai, W. Evaluating China's regional collaboration innovation capability from the innovation actors perspective-An AHP and cluster analytical approach. Technol. Soc. 2013, 35, 182-190. [CrossRef]

71. Pham, H.-H.; Lai, S.L.; Vuong, Q.-H. The Role of Subjective Task Value in Forming Satisfaction and Loyalty Among Vietnamese International Students: A Structural Equation Model. Asia-Pac. Educ. Res. 2019, 28, 399-409. [CrossRef]

(C) 2020 by the authors. Licensee MDPI, Basel, Switzerland. This article is an open access article distributed under the terms and conditions of the Creative Commons Attribution (CC BY) license (http://creativecommons.org/licenses/by/4.0/). 